\title{
Polysèmes
}

Revue d'études intertextuelles et intermédiales

\section{Reconstructing Gothic Architecture in Ann Radcliffe's Novels: from Decorative Details to Picturesque Tableaux}

Du détail décoratif au tableau pittoresque : la reconstruction de l'architecture gothique dans les romans d'Ann Radcliffe

\section{Alice Labourg}

\section{OpenEdition \\ Journals}

\section{Electronic version}

URL: http://journals.openedition.org/polysemes/4637

DOI: $10.4000 /$ polysemes.4637

ISSN: 2496-4212

\section{Publisher}

SAIT

\section{Electronic reference}

Alice Labourg, « Reconstructing Gothic Architecture in Ann Radcliffe's Novels: from Decorative Details to Picturesque Tableaux », Polysèmes [Online], 21 | 2019, Online since 30 June 2019, connection on 11 June 2019. URL : http://journals.openedition.org/polysemes/4637 ; DOI : 10.4000/polysemes.4637

This text was automatically generated on 11 June 2019.

Polysèmes 


\title{
Reconstructing Gothic Architecture in Ann Radcliffe's Novels: from Decorative Details to Picturesque Tableaux
}

\author{
Du détail décoratif au tableau pittoresque : la reconstruction de l'architecture \\ gothique dans les romans d'Ann Radcliffe
}

Alice Labourg

1 The main legacy of the Gothic Revival in literature is the Gothic novel. Horace Walpole not only built the first modern Gothic villa, Strawberry Hill, but he also wrote the first Gothic novel, The Castle of Otranto. The novel might be seen as an imaginary extension of his architectural fantasy as he started writing it after he had a dream of a "gigantic hand in armour" resting on the banister of a staircase in an ancient castle. ${ }^{1}$ Some twenty years after Walpole's dream, the Gothic novel had developed into a literary genre of its own of which Ann Radcliffe was one of the most popular representatives. The influence of the Gothic Revival is obvious from the importance given to Gothic architecture in her narratives. Ruined castles, abbeys or monasteries form part of the staples of the genre, the prerequisite decor for any real action to happen. According to Maurice Lévy, a Gothic novel is "Gothic" because its writing is closely related to architecture (Lévy 1968, v). The story is indeed the very dramatization of a building, a Gothic building, or more precisely, a building perceived as Gothic. The aim of this paper is to explore the aesthetic dimension of Gothic architecture in Radcliffe's novels, especially in terms of its pictorial and visual effects, from decorative emblematic details that stamp a building as Gothic to the creation of picturesque "tableaux" composed as true "paintings in words". 


\section{The Gothic motif}

2 The Gothic Revival rediscovered the old style as an aesthetic form. It decomposed monumental structures into ornamental motifs, picturesque details pleasing for their visual and plastic qualities, their irregularities and intricacies, versatile enough to be deterritorialized and reterritorialized as flimsy decorative elements that could be adapted to interior decoration and furniture. Radcliffe transfers this ornamental Gothic into the realm of the novel-in itself a new and also versatile form-, adapting the ancient style of the "Goths" to modern dramatic purposes. Pointed windows with stained glass, lofty arches, embattled towers and vaulted ceilings are the emblematic architectural features used to identify a building as Gothic in style in her novels. The mention of these elements, to borrow Barthes's expression, creates "a reality effect" (see Barthes). It sustains the verisimilitude of the location, both in time and space, while serving as a fuel for the imagination. It also helps generate specific moods suiting the development of the action.

3 Stained glass was historically used in religious buildings to let light flood in as a sign of the presence of God. As in Strawberry Hill where, according to Walpole, it brought a pleasing sense of "gloomth", , painted glass in Radcliffe's novels is not associated with light but with darkness and, as a consequence, with the terror of the Burkean sublime. When Osbert is brought to a secure cell within the castle of Dunbayne, the mention of the "Gothic windows partly excluding light" is meant to convey a sense of claustrophobic oppression as the obscurity of the place almost chilled the young man to "horror" (Castles, 49). ${ }^{3}$ Likewise, the very unrealistic "painted window, stretching nearly from the pavement to the ceiling" in the entrance hall of Udolpho is designed to impart a sense of awe to the heroine-and the reader-as it turns the castle into a sort of pagan cathedral ( Udolpho, 228). The window operates a symbolic reversal between transparency and opacity as the light coming from the incongruous tripod hanging from the ceiling makes it visible only to underline the very lack of visibility it provides. The window is an opaque screen that prevents one from seeing outside, turning the gaze inwards to the infinite inner architectural landscape of the castle. Its presence symbolically suggests that the heroine has entered another world, a dystopic universe where common dichotomies and their related values are subverted.

The painted window is a symbol of literal and metaphorical gloom because, for the "enlightened" Protestant mind, it is synonymous with Catholic superstition as the abbey of St Augustin exemplifies: "The dim glass of the high-arched windows, stained with the colouring of monkish fictions, and shaded by the thick trees that environed the edifice spread around a sacred gloom, which inspired the beholder with congenial feelings" ( Sicilian, 117, my emphasis). The polysemy of the word "stained" underlines this dual articulation while the pictorial metaphor enhances the iconic visual effect, involving both place and mind in a literal and figurative chiaroscuro.

5 Radcliffe ambiguously plays with the religious connotation of the stained-glass window and its "sacred gloom" to arouse the reader into superstitious dread, an essential component of the thrilling pleasure derived from reading Gothic fiction: "[...] he often looked forward into the sacred gloom, which the painted windows threw over the remote perspective, in the expectation of perceiving a monk" (Italian, 103). The window is a common literary metaphor for the mind and the painted glass, dimming the outside light, 
makes it a lens that reflects the feelings of the heroine: "She continued walking in the gallery, till evening threw its melancholy twilight through the painted casements, and deepened the gloom of the oak wainscoting around her; while the distant perspective of the corridor was so much obscured, as to be discernible only by the glimmering window, that terminated it" (Udolpho, 384). The word "perspective" transforms the architectural space into a pictorial device for the projection of the heroine's subjectivity as confirmed by the hypallage "melancholy gloom".

6 At Dunbayne, the painted window becomes a pregnant detail in Osbert's secret exploration of the castle from his cell. The secret panel lets him into an "apartment wide and forlorn, like that which formed his prison" with "high and arched [windows] decorated with painted glass", indicating that the room used to be a "place of worship" ( Castles, 51). The abandoned state of the chapel stands a witness to the moral deliquescence of the building and its inhabitants. The stained-glass casements in the next room which he visits are "shaded by thick ivy that almost excluded the light" (Castles, 52). Both the painted glass and the creeping vegetation are palimpsestic traces pointing to an even more ancient "Gothic" past than the already medieval timeframe of the narrative. Space and time overlap: by retracing the "archaeology" of the building, Osbert engages in a literal and metaphorical journey which leads him to unravel the secret history of the castle and the source of Malcolm's usurped power as he discovers its legitimate owner and her daughter sequestered for years in a remote apartment.

7 Through repetition with variations, the motif of the painted window increases the oneiric dimension of the character's wanderings through the architectural maze. When Emily steps down to the burial chamber of the chapel at Udolpho, its mention along with some other decayed architectural elements functions as a sort of visual warning sign for the heroine: "She looked fearfully on the almost roofless walls, green with damps, and on the gothic points of the windows where the ivy and the briony had long supplied the place of glass, and ran mantling among the broken capitals of some columns, that had once supported the roof' (Udolpho, 344). The creeping vine has completely displaced the religious painted glass, presenting to the eye a symbolic sign of dereliction and doom.

The Gothic is an aesthetics of the surface that favours ornamentation (see Sedgwick and Reeve). The sublimity of the painted window may be softened by the picturesque as shown in the hybrid window of the convent of St Clair, "the lower panes of which, being without painting, allowed [Blanche] to observe the progress of the storm over the Mediterranean" (Udolpho, 484). The ornamental trick thus conveniently constructs the view into a seascape. The Gothic window in itself is indeed essential as a scopic device to frame a pictorial scene. The domestication of the abbey of Fontanville proves a case in point. Madame La Motte chooses a "vaulted apartment" as a sitting room because "its large Gothic window, that descended almost to the floor, admit[s] a view of the lawn, and the picturesque scenery of the surrounding woods" (Forest, 32). At Chateau-le-Blanc, the "vast gothic window, embroidered with clematis and eglantine" that adorns the hall provides the perfect decorative framing for the transformation of the prospect, gradually extending from the surrounding lawn and woods to "the waters of Mediterranean [...] lost in the horizon", with the "luxuriant shores of Languedoc and Provence" and "the majestic Pyrenées [sic]" on either side, into the literary equivalent of a landscape painting (Udolpho, 469). The embroidery motif, which echoes the tapestries hung on the walls, is a metatextual-not to say a metapictorial-image of Gothic writing as a textual weaving of 
pure narrative passages with pictorial landscape descriptions constructed as wordpictures. $^{4}$

9 Another emblematic Gothic motif used for pictorial effects is the arch. The arch is a frame that makes figures emerge in a phenomenological way as in a painting. The figure Hippolitus sees standing under an archway of the monastery in ruins creates a sort of "micro-picture", between the pictorial and the spectral (Sicilian, 160). The arcade marks a symbolic threshold and the figure acts as a go-between, leading Hippolitus inside the building as if he were entering a picture. The structural device is duplicated as the hero stands a helpless voyeur watching a man being molested by brigands from another internal window before he discovers his beloved struggling in the arms of some ruffians in another part of the pile (160-164). The encounter between Emily and the men on the ramparts is also staged in a pictorial mode. The figures seem to appear under the arch as the result of the animation of the architecture under the strong chiaroscuro:

She turned to observe a fine effect of the sun, as his rays, suddenly streaming from behind a heavy cloud, lighted up the west towers of the castle, while the rest of the edifice was in deep shade, except, that, through a lofty gothic arch, adjoining the tower, which led to another terrace, the beams darted in full splendour, and shewed the three strangers she had observed in the morning. (Udolpho, 287)

The uncanny effect enhances the sexual undertones of the episode. Likewise, the mysterious monk in The Italian emerges as a spectral figure from under the arch of the ruins of Paluzzi.

The potential for visualisation in both scenes is exploited in the Limbird illustrated edition of 1824 (fig. 1 and 2). Reversing the text, the illustrators have chosen to make the hero/ine, and not the villains, appear under the arch. Providing a frame within the frame of the illustrative vignette, the arcade makes the good character stand out, thus encouraging sympathetic involvement while increasing the sensational dimension. Emily, all in white, wrapped in the iconic billowing veil of Venus and looking away at the landscape, visually supports the erotic charge (fig. 1). The reader adopts the perspective of Montoni's men who, in the text, look at her and whisper to each other in earnest as she walks past, modestly drawing her veil closer. Vivaldi's unexpected encounter with the monk (fig. 2) is also staged so as to set forward the reaction of the former as he faces the reader-spectator while the latter is represented from behind in three quarters, his countenance hardly visible under his cowl.

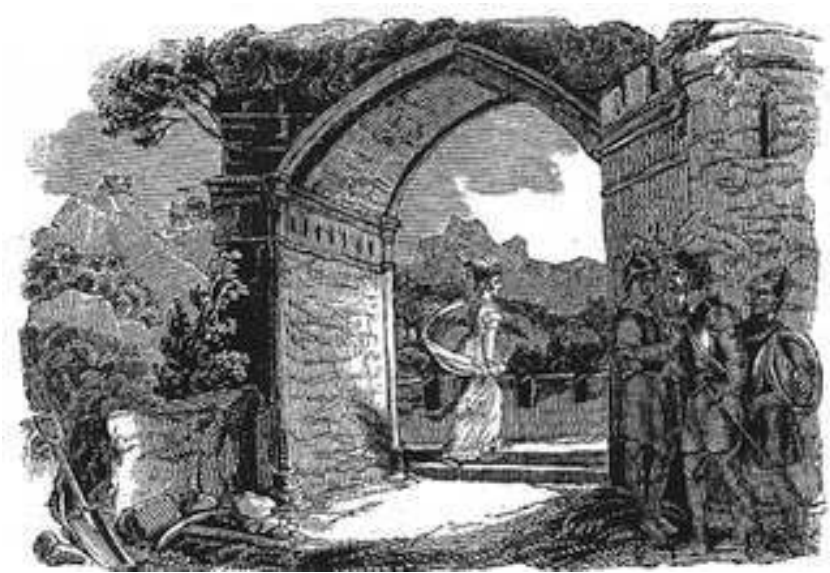

Fig. 1. Anonymous, The Mysteries of Udolpho (1824), London: J. Limbird, wood engraving, 10x7 cm. CBRITISH LIBRARY BOARD, 12613.H.12/13, 145. 


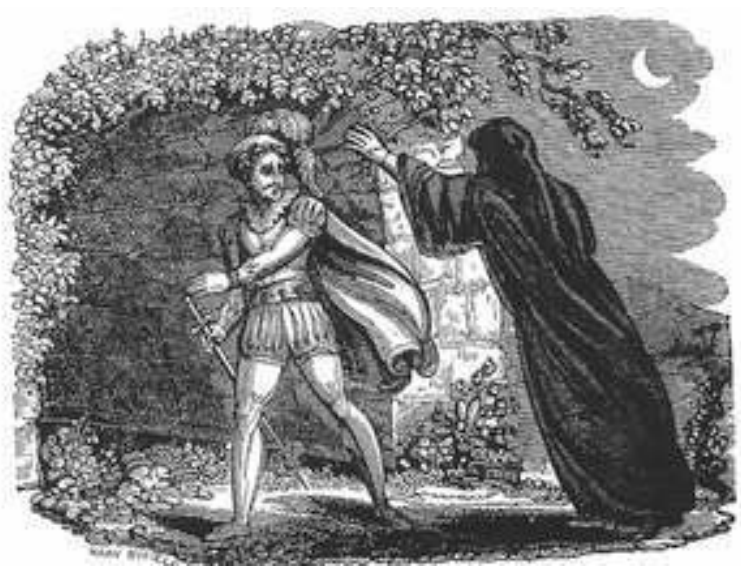

Fig. 2 Mary Byfield, The Italian (1824), London: J. Limbird, wood engraving, $9.5 \times 7 \mathrm{~cm}$. CBRITISH LIBRARY BOARD, 12613.H.12/16, 7.

That the ruins of Paluzzi are Roman proves that a building does not necessarily have to be Gothic in style to be Gothic in mood. The Gothic novel indeed provides its own definition of what a Gothic building is. First, it has to be in ruins. Then, it displays a labyrinthine space where one gets lost physically and mentally. Standing as a sublime object of terror, it is an archetypal site of otherness, a matrix of unconscious fears and desires, a place of live burial (see, among others, Sedgwick, Lévy and Durot-Boucé). The description of the fortress of Paluzzi recalls the famous engravings of Roman ruins made by Giovanni Battista Piranesi in his Vedute di Roma. One representation of Cecilia Metella's tomb on the Via Appia Antica features the same kind of arch attached to a round main building that characterizes the fortress (fig. 3). To confront Schedoni, Vivaldi actually compares the drawing of a Roman ruin in the Marchesa's collection to the ruins of Paluzzi (Italian, 49). In a kind of reversed ekphrasis, he describes the work before him as if it were the ruins of Paluzzi, adding the conventional figures of lurking banditti, or, more appropriately, that of a threatening friar, to "finish the piece" and reflect his own experience. Blurring reality and fiction, model and representation, Vivaldi's pictorial rewriting of his encounter with the terrible monk may read as a metatextual comment on the writing itself and its creation of "Landscapes with Ruins" and vedute-like "pictures" as an integral part of storytelling. 


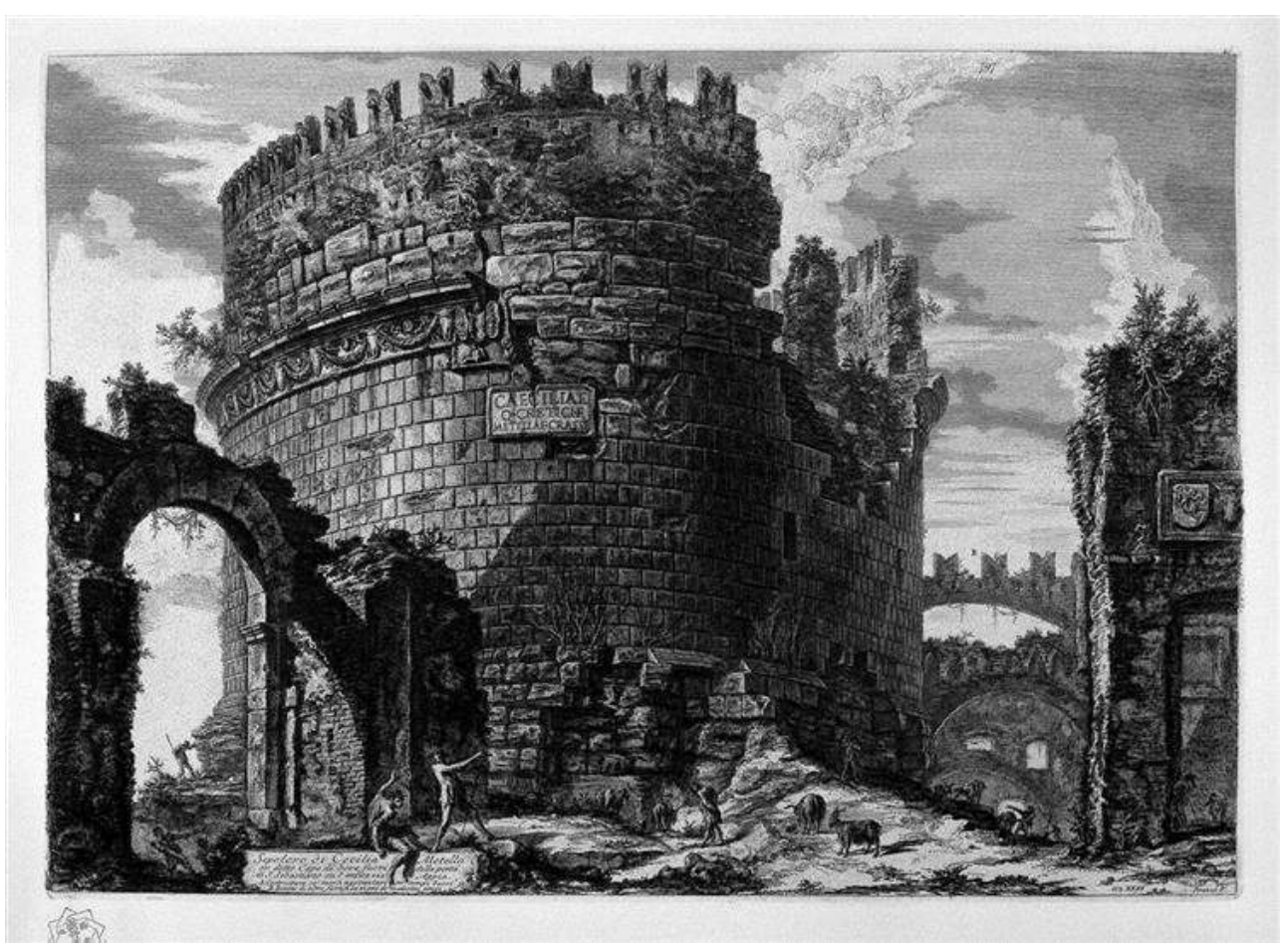

Fig. 3. Giovanni Battista Piranesi, "Tomb of Cecilia Metella", Vedute di Roma (1762), etching, $45 \times 63.5 \mathrm{~cm}$, Minneapolis Institute of Arts, Minneapolis.

C)CREATIVE COMmons.

Critics like Lévy, Clery or Durot-Boucé have indeed associated Radcliffe's architectural creations with Piranesi's engravings, especially his Carcieri d'Invenzione. These imaginary prisons are a visual illustration of the Burkean sublime showing dark, infinite, labyrinthine spaces that are Gothic in spirit if not always in style. They are architectural nightmares that oppress the viewer by the weight of their sheer immensity. The black marble hall at Mazzini, with its "lofty roof" and "high and gothic windows", its "air of proud sublimity", and the "several gothic arches, whose dark shade veiled in obscurity the extent beyond" (Sicilian, 46), the great hall at Udolpho, or the arch-supported inner apartment that holds the Inquisition, whose "long arcades branched off from every side of the chamber, as from a central point" (Italian, 197), are Piranesian and the mention of specific Gothic architectural details increases their sublimity. Gothic architecture actually engenders various emotional responses from pleasant melancholy to sublime dread. Seen from inside, a Gothic building generates sublime terror. Seen from outside, and integrated in its natural surroundings, it is a picturesque object, in keeping with William Gilpin's principles. Radcliffe thus capitalizes on the visual appeal of Gothic ruins to create "picturesque tableaux", revisiting "the Landscape with Ruins" as a pictorial genre to create true "paintings in words". ${ }^{5}$

\section{"Landscapes with Gothic ruins"}

13 In the seventeenth-century classical landscape, ruins were Roman as in Claude Lorrain's or even Salvator Rosa's paintings. As the Gothic revival introduced Gothic ruins and follies into the English landscape garden alongside classical follies, Gothic architecture also became a new subject for paintings. The illustrations from antiquarian books and the views of the topographers popularized Gothic castles, abbeys and monasteries as national 
visual icons. Thomas Girtin and the young William Turner started their careers as topographers but soon provided a more sensitive and plastic rendering of the ruins (fig. 4). Another "English Claude", Richard Wilson, infused national scenery and heritage monuments with Italian overtones while preromantic artists such as Joseph Wright of Derby staged Gothic architecture under the strong chiaroscuro of the moonlight thus arousing new emotional responses (fig. 5 and 6 ).

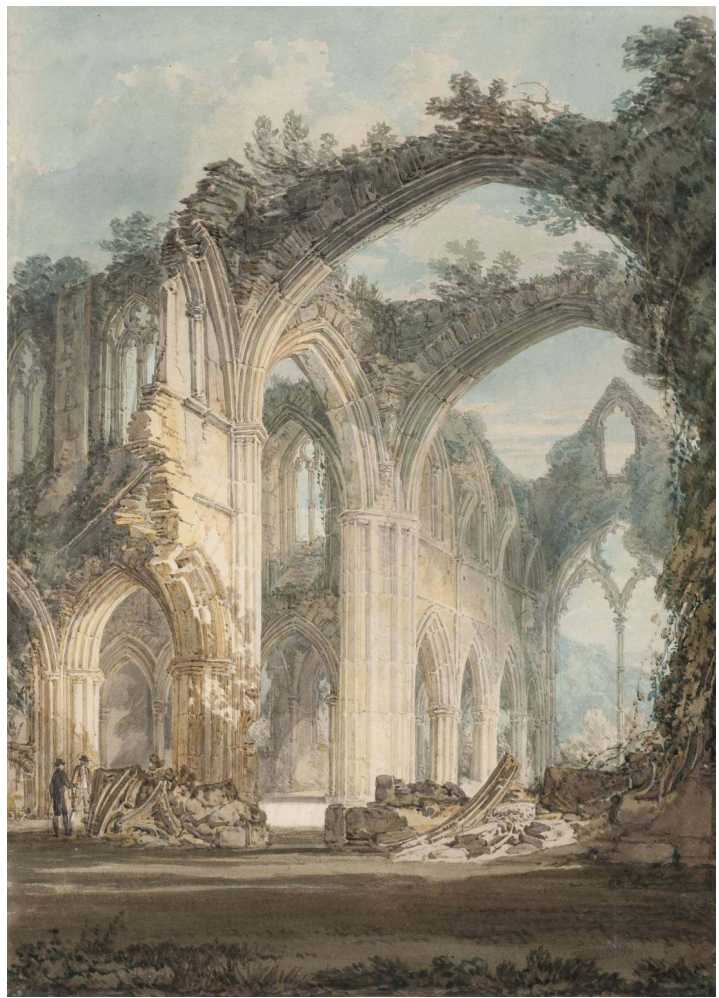

Fig 4. Joseph Mallord William Turner, Tintern Abbey: The Crossing and Chancel Looking Towards the East Window (1794), graphite and watercolour on paper, $35.9 \times 25 \mathrm{~cm}$, Tate Britain, London.

(c) Creative Commons. 


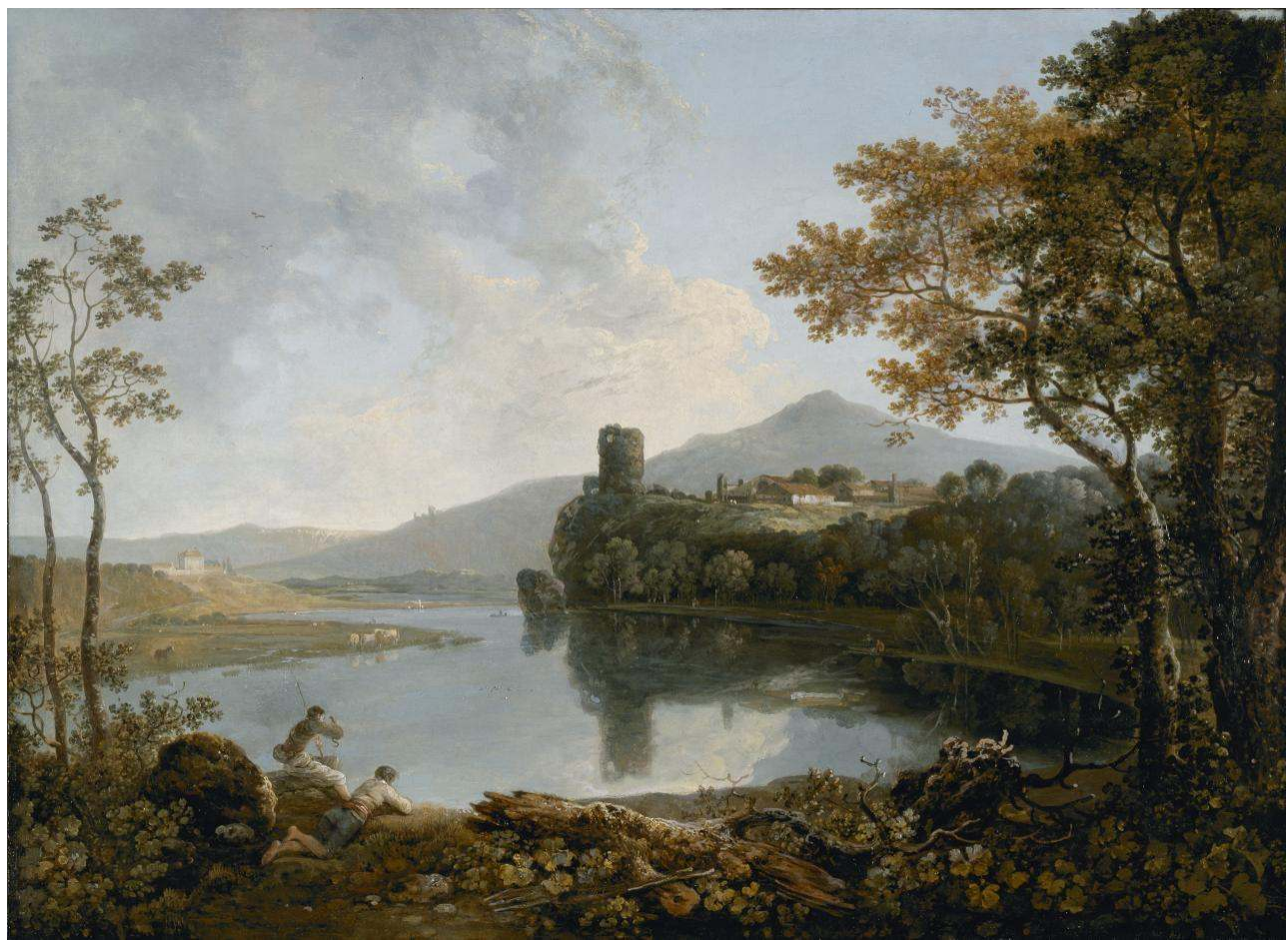

Fig. 5. Richard Wilson, Llyn Peris and Dolbadern Castle (c. 1764-1765), oil on canvas, 92.7x125.7 cm, National Museum Wales, Cardiff.

CNATIONAL MUSEUM WALES, CARDIFF.

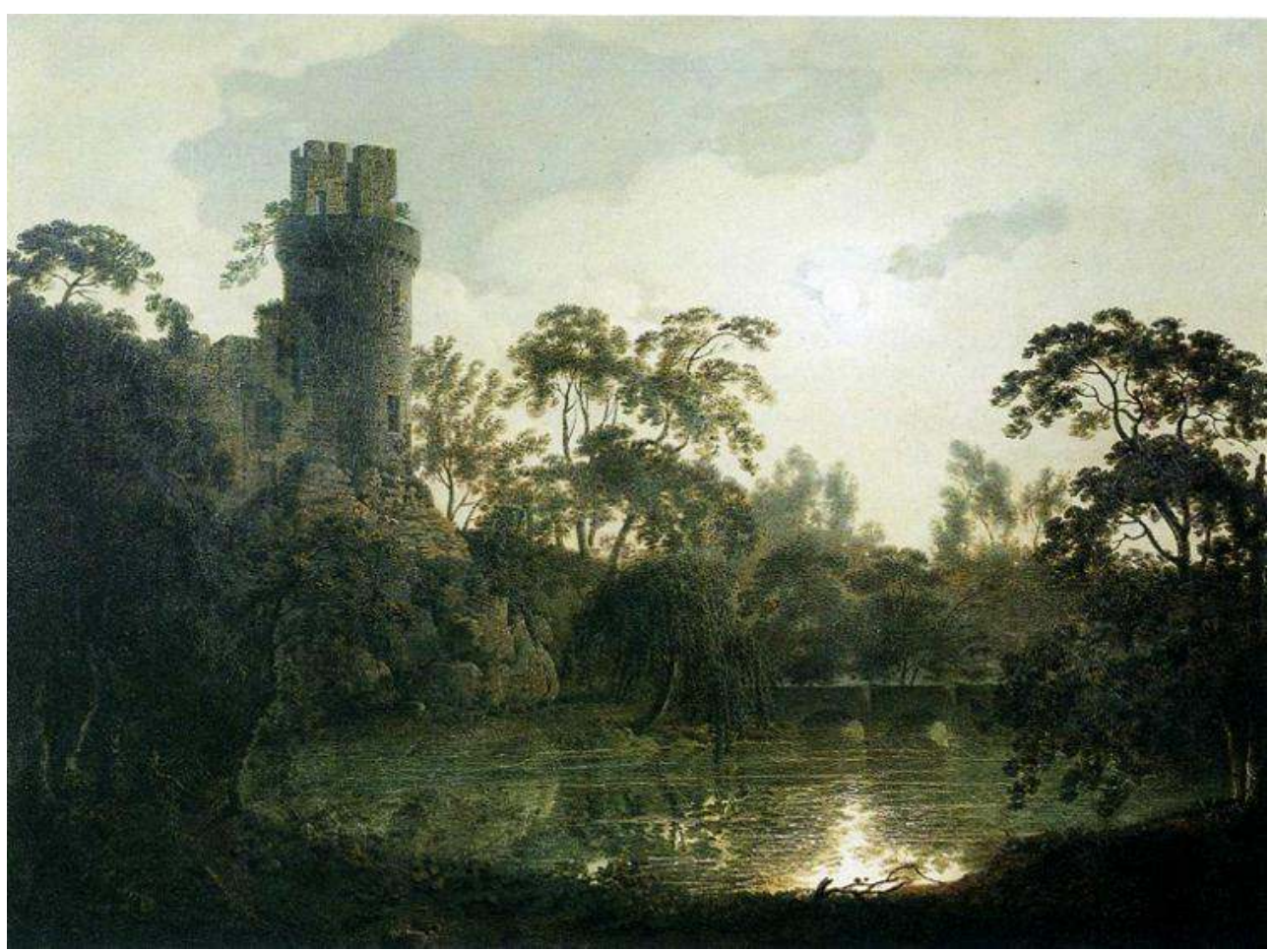

Fig. 6. Joseph Wright of Derby, Moonlight with a Lake and a Castellated Tower (c. 1787), 58x76.2 cm, oil on canvas, private collection.

(c) Creative Commons.

14 Many descriptions in Radcliffe's novels have a visual quality that recalls these kinds of representations. They appear like "paintings in words", literary versions of pictorial 
"Landscapes with Gothic Ruins" in which Gothic architecture is reconstructed through iconotextual techniques. ${ }^{6}$ The novelist invests the intrinsic visual qualities that, according to the new aesthetics of the time, make Gothic architecture picturesque, that is to say, "worthy of the pencil" (Italian, 185). ${ }^{7}$ Classical rules rejected the Gothic because of its irregularity, asymmetry, roughness and lack of proportion. These are the very qualities sought after by the amateurs of the picturesque. For Gilpin, the Gothic ruins that "adorn" the English countryside are naturally picturesque, and doubly so, since in their general quality as ruins, consecrated by time and mellowed by the passing of years, they are almost an organic component of the national soil, and, specifically, as Gothic ruins, covered with creeping vegetation, they mimetically fuse with their environment, in keeping with Bishop Warburton's theory of the sylvan origin of Gothic architecture (Gilpin 1794, 46; 1786, 183). Besides, the rough surfaces of their decaying grey stones catches the changing lights in a variety of ways while thick ivy offers pleasant contrast of colours (Gilpin 1782, 48).

Radcliffe makes use of all these qualities to pictorialize the Gothic piles so central to her narratives. ${ }^{8}$ The monastery in ruins discovered by Hippolitus is first dramatized as some towers emerging from the woods, revealed by the moonlight (Sicilian, 159). The image, as textual as it is pictorial, draws on a literary cliché Marie-Madeleine Martinet has identified as the quintessential Gothic motif: "Towers and Battlements it sees, / Bosom'ed high in turfed Trees". The distich, from Milton's Allegro (1. 77-78), is quoted by Gilpin in his description of the Gothic Temple at Stowe. The image of towers emerging above trees, or that of a building partly revealed throughout the trees, is often used to introduce a new setting in a sort of picturesque vignette, adding lighting effects that enhance the sense of mystery. In the case of the abbey of Fontanville, the framing device of the carriage window and the use of a character as focalizer increase the pictorial dimension: "[A]s La Motte looked anxiously from the window, he observed upon the vivid glow of the western horizon, some dark towers rising from among the trees at a little distance" ( Forest, 14).

According to Lévy, the following description of the abbey (Forest, 15) provides "a wonderful example of Gilpinesque word-painting" and could have been drawn by Turner (Lévy 1996, 41). The comparison to the visual arts actually goes beyond mere paragonesque analogy as painting pervades the text on a formal as well as thematic level. Set within the textual unit of a paragraph, the hypotyposis turns into a "painting in words" by drawing on the Gothic motif: "He approached, and perceived the Gothic remains of an abbey. It stood on a kind of rude lawn, overshadowed by high and spreading trees, which seemed coeval with the building, and diffused a romantic gloom around". The hypallage in the "pantomyne", the phrase introducing the object of the description (Hamon), puts forward the word "Gothic" by making the adjective refer to "remains" and not "abbey". The semantic displacement underlines the ruin-like quality of the ruin while metatextually reflecting on the generation of the iconotextual "Landscape with Ruins", as well as on the very aesthetics of the fragment, which, according to Martinet, stands at the core of the picturesque Gothic.

The writing indeed proceeds metonymically from the general to the particular. The parts mirror the whole: each Gothic element is individualized as an iconic and synecdochic detail, a fractal variation of the entire building seen as an icon melting with the trees: "The lofty battlements, thickly enwreathed with ivy, were half demolished [...]. Huge fragments of the eastern tower, which was almost demolished, lay scattered amid the high 
grass [...], a window of the same order, whose pointed arches still exhibited fragments of stained glass" (Forest, 15, my emphasis). Ruins within the ruin, all the archetypal elements are likewise both fragmented and related to the vegetation. Symbolically, only the entrance gate is intact ("a Gothic gate, richly ornamented with fret-work, [...] obstructed with brush-wood, remained entire"), enabling to get access to the fabric and ultimately domesticate the Gothic by inhabiting it.

Each architectural detail becomes in itself an icon of gothicity, a visual form deprived of its religious function, as with the painted glass, "once the pride of monkish superstition", and invested with emotional significance through the picturesque. The description insists on the very style of the building as a source of sublimity through the repetition of the word "Gothic" and the periphrasis "the same order", while more architectural vocabulary ("fabric", "battlement", "tower", "fret-work", "pointed arch", "stained glass") pervades the text. Obscurity ("overshadowed", "romantic gloom"), verticality and immensity ("lofty battlements", "huge fragments", "vast and magnificent portal") are all characteristics of the Burkean sublime.

The convent of Saint Clair, approached from below as in a topographical view (Charlesworth 77), provides another example of the pictorial reconstruction of Gothic architecture:

$[T]$ he boat soon after doubling a lofty head-land, the monastery of St. Claire appeared, seated near the margin of the sea, where the cliffs, suddenly sinking, formed a low shore within a small bay, almost encircled with woods, among which partial features of the edifice were seen;--the great gate and gothic window of the hall, the cloisters and the side of a chapel more remote; while a venerable arch, which had once led to a part of the fabric, now demolished, stood a majestic ruin detached from the main building, beyond which appeared a grand perspective of the woods. (Udolpho, 483)

The emblematic architectural elements are this time seen through the screen-like trees. The punctuation suggests fragmentation as the dash detaches the iconic details from the rest of the sentence introducing the view as a whole. In conjunction with "while", the half column plays on dislocation and integration to throw into relief another archetypal structure-the arch. Both a particolare and a detaglio, ${ }^{9}$ the arch forms a picture within the picture, the decorative creepers adding a Gilpinian detail to the modulation of the Gothic into the picturesque: "On the grey walls, the moss had fastened, and, round the pointed windows of the chapel, the ivy and the briony hung in many a fantastic wreath" (Udolpho, 483). Demolished by the Reformation, deprived of its utilitarian function but still a signifier of connection and passage, the arch stands as a symbol of the reintegration of the Catholic ruin into the national soil as a picturesque element, an image of pacification and reconciliation with the troubled national past.

The ruined Saxon fortress in the Pyrenees (Udolpho, 606) presents another symbolic picture. It first appears as a single tower illuminated by the ray of the moon as in composition by Wright of Derby, before, as the gaze comes closer, expanding and metamorphosing into an imposing fortress in the moonlight (604). Here again, the description insists on the ruinous state of the fabric while typically mentioning that many parts are still entire, which renders it inhabitable for appropriate pictorial "figures" in the presence the smugglers (605). The picturesque gradually shifts towards the fantastic in an amplification of the Gothic motif. The oak, an emblem of Anglo-Saxon liberties, like Gothic architecture ${ }^{10}$ and praised by Gilpin in his Remarks on Forest Scenery, is described as a ruin within the ruin: 
In this court of entrance stood the gigantic remains of an oak, that seemed to have flourished and decayed with the building, which it still appeared frowningly to protect by the few remaining branches, leafless and moss-grown, that crowned its trunk, and whose wide extent told how enormous the tree had been in a former age (Udolpho, 606, my emphasis).

The vegetal fuses with the mineral: it is no longer the Gothic architecture that imitates natural forms but the vegetation that becomes a Gothic ruin. Visual correspondences enhance the mirror effect as, to the "enormous round towers" correspond the large trunk and branches, which in turn echo the round arches of the gate and windows ("arch of the gate [...] was round [...] as was that of the windows above"). The adjectives denoting the sublime reinforce the "super-natural" dimension: "terrible even in ruins [...], heavy Saxongothic style [...] enormous round towers [...] large gate [...] huge mass of ruins [...] gigantic remains of an oak [...] wide extent [...] how enormous the tree had been [...] great strength [...] deep glen [...] great power" (my emphasis). As a ruin, the fortress has gained in psychological impact what it has lost as a concrete defensive structure, as suggested by the polyptoton: "the air of solemnity, which must so strongly have characterised the pile even in the days of its early strength was now considerably heightened" (606, my emphasis). The presence of such a Gothic structure on a Catholic soil may be seen as a political statement. Its strength and resilience makes it a symbolic site of empowerment and resistance of Anglo-Saxon values in the contextual turmoil of the French Revolution.

The novels as a whole can actually be seen as the dramatization of various landscape paintings as the prologue of A Sicilian Romance suggests. It introduces the castle of Mazzini as a picturesque ruin in a landscape contemplated by a tourist on his Grand Tour. The novel thus reads as the animation of that very picture. Integrated in its natural environment, magnified by the purple setting rays of the sun or the silvery gleam of the moon, the Gothic ruin has a strong visual and psychological appeal that kindles the imagination. From that point of view, the arrival at the castle of Udolpho is certainly Radcliffe's most striking word-painting. It combines Claudian atmospherical effects with the typical Salvatoresque mountainous landscape to present the castle as a "gloomy and sublime object", "the Gothic greatness of its features and its mouldering walls of dark grey stone" being transfigured by the purple rays of the setting sun in a vibrant chiaroscuro (Udolpho, 226-227).

The overall view from afar is followed by a closer focus on the castle in which Gothic architectural details become proleptic symbols of the fate awaiting the heroine within. The castle indeed appears like a giant instrument of torture as more technical vocabulary comes to saturate the description:

[T] he gloom, that overspread it, allowed her to distinguish little more than a part of its outline, with the massy walls of the ramparts, and to know, that it was vast, ancient and dreary. From the parts she saw, she judged of the heavy strength and extent of the whole. The gateway before her, leading into the courts, was of gigantic size, and was defended by two round towers, crowned by overhanging turrets, embattled, where, instead of banners, now waved long grass and wild plants, that had taken root among the mouldering stones, and which seemed to sigh, as the breeze rolled past, over the desolation around them. The towers were united by a curtain, pierced and embattled also, below which appeared the pointed arch of a huge portcullis, surmounting the gates: from these, the walls of the ramparts extended to other towers, overlooking the precipice, whose shattered outline, appearing on a gleam, that lingered in the west, told of the ravages of war. (Udolpho, 227) 
The "massy walls of the ramparts" connote oppression and enclosure. The defensive structure of the building is emphasised with such words as "defended" or "embattled" (repeated twice). The phallic and aggressive towers are even redoubled in their very structure ("two round towers, crowned by overhanging turrets"). The pointed and sharp aspect of the architectural elements is furthermore underlined by the blunt sound of the plosives ("pierced", "pointed", "portcullis"). Combined with the dentals ("towers", "unit ed", "curtains", "pierced", “embattled", "pointed", “portcullis", "gates”), it emphasizes the torture imagery. Violence is inscribed in the very walls of the building ("other towers [...] whose shattered outline [...] told of the ravages of war"). The weeds have replaced the banners, symbols of civilization. Personified as they seem to "sigh" under the breeze, they are like plaintive, emaciated bodies, strips of flesh hanging down, suggesting the image of a tortured body on a rack.

Once inside the court, Emily explicitly associates the vegetation on the walls with images of "suffering and murder" (228). To develop Ann Ronald's suggestion of "a variety of sexual organs and actions" (Ronald 179), one may point to the phallic towers and angularshaped architectural elements as more precisely suggesting a symbolic rape. The gate opens on what might be regarded as a gaping female sex, surmounted by a clitoral portcullis while the pierced curtain in-between the towers stands for a deflowered hymen. The castle is indeed the place where Emily will be confronted with sexuality and death as emblematized in the notorious veiled picture. The reference made to "banditti starting up from under a tree" (227) enhances the visual appeal by pointing to a specific pictorial model which also frames the description: the so-called "Landscape with Banditti”. ${ }^{11}$

\section{Gothic “Landscapes with Banditti”}

Radcliffe, in a way, synthesized the Gothic revival in architecture and the "Landscape with Banditti" in painting. This pictorial subgenre, derived from the late works of baroque Neapolitan painter Salvator Rosa, was very popular at the end of the eighteenth century. While Claude's classical compositions embodied the beautiful, Salvator's rocky landscapes, inhabited by weird soldier-banditti-like figures, were regarded as the very illustration of the sublime, or of a darker form of the picturesque (see fig. 7). ${ }^{12}$ Fear of encountering banditti when crossing mountainous landscapes, or coming close to some forsaken ruin that might be their "haunt", is a leitmotiv in the novels (Forest 14, 73, 80, Udolpho 38, 86, 501, Italian, 113, 148). The allusions not only increase suspense but also function as triggers for the imagination, bringing to mind the popular images of Rosa's "Landscapes with Banditti" and of his eighteenth-century imitators. The explicit reference to "Salvator" during the crossing of the Pyrenees overtly acknowledges the extradiegetical pictorial model (Udolpho, 30). 


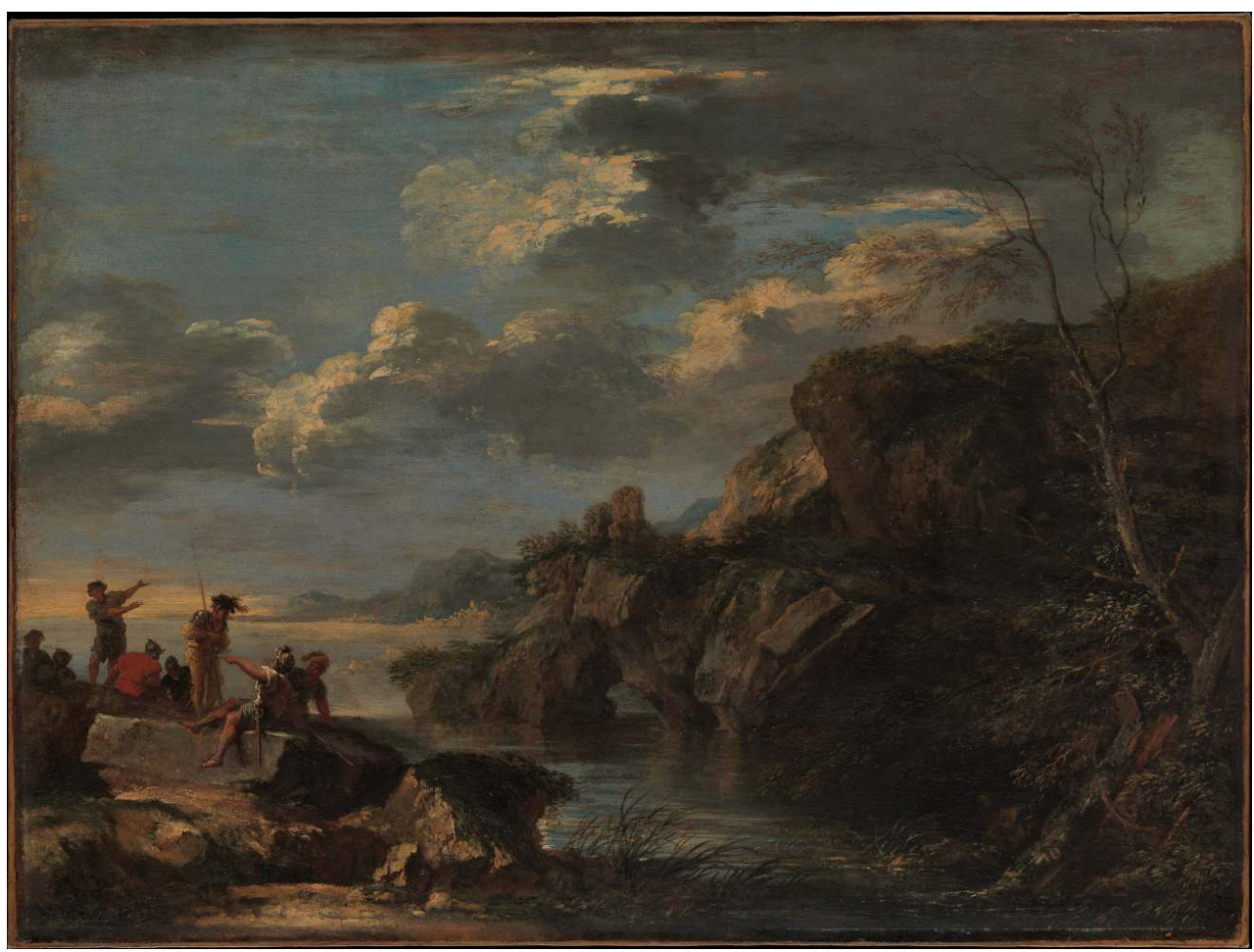

Fig. 7. Salvator Rosa, Bandits on a Rocky Coast (1655-60), oil on canvas, 74,9x100 cm, Metropolitan Museum of Art, New York.

(c) Creative Commons.

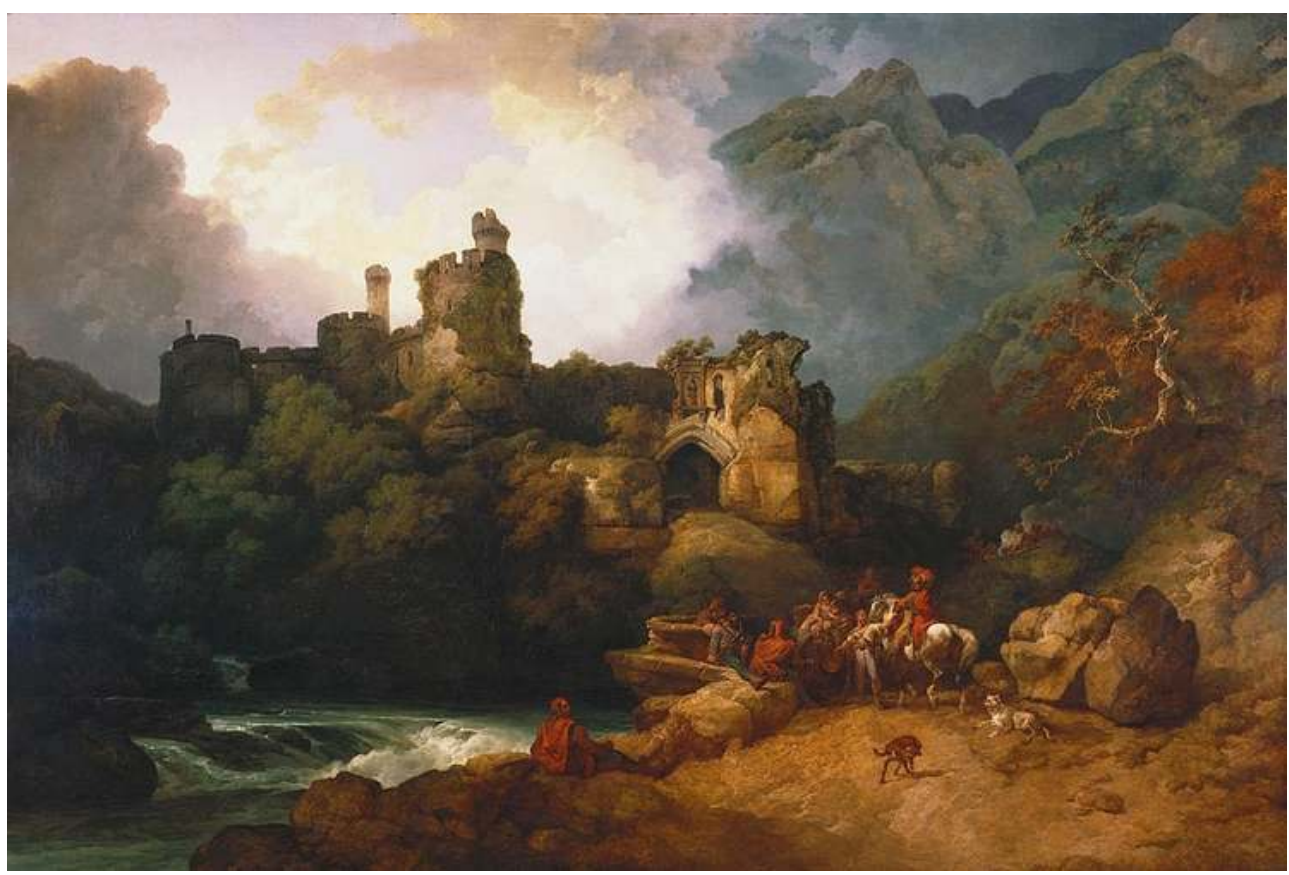

Fig. 8. Philip-James de Loutherbourg, Banditti in a Landscape (1804), oil on canvas, 372.8×250.1 cm, Royal Collection, Windsor Castle.

CROYAL COLLECTION 


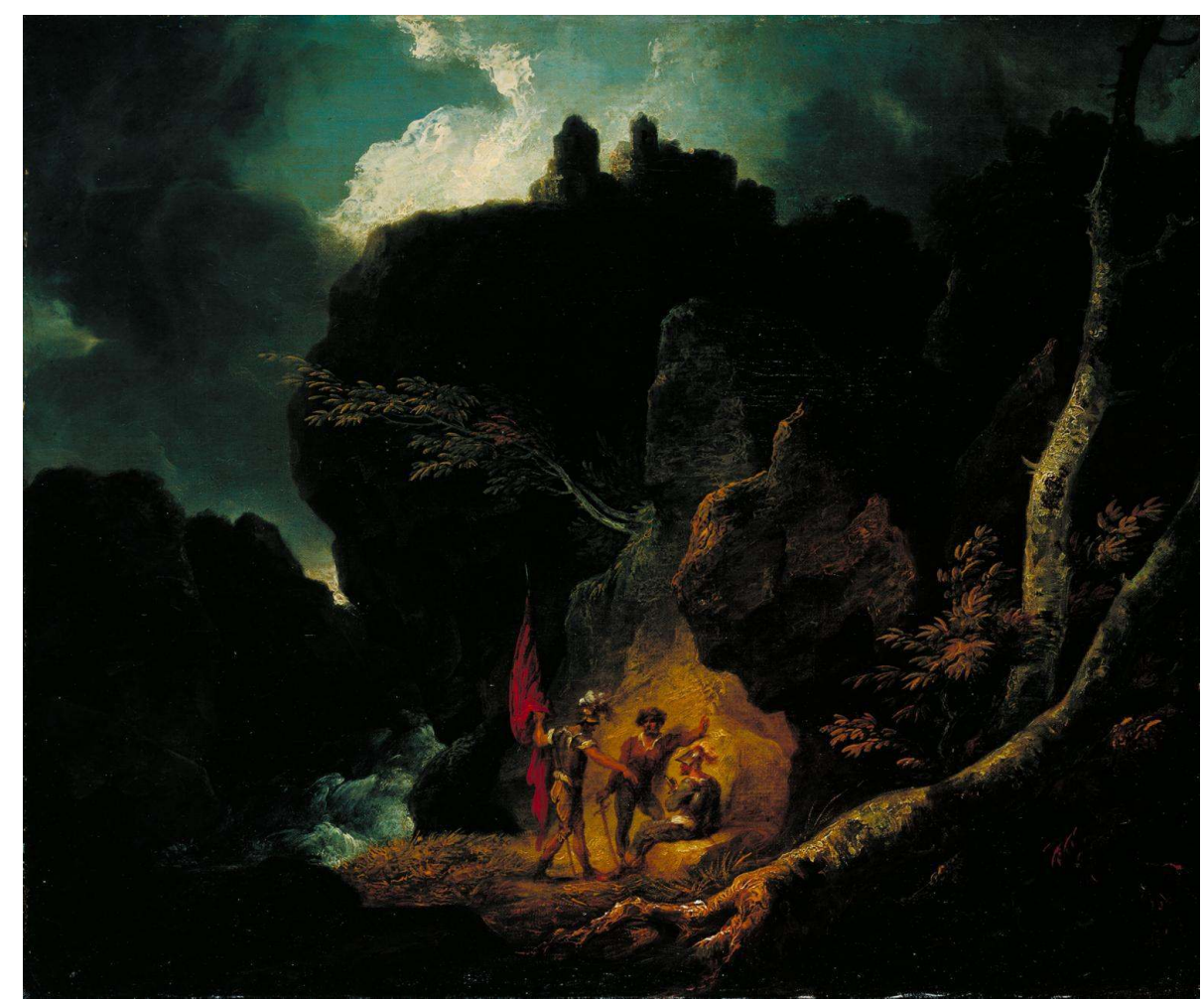

Fig. 9. John Hamilton Mortimer (manner of), Rocky Landscape with Banditti (c. 1770-80), oil on canvas, $50.2 \times 60.3 \mathrm{~cm}$, Tate Britain, London.

(c) Creative Commons

Contemporary painters, like Philip-James de Loutherbourg or John Hamilton Mortimer, had already "gothicised" the Salvatoresque paradigm by integrating Gothic ruins into their compositions (fig. 8 and 9). Radcliffe carries on that trend by inserting banditti into architectural decors. In fact, many scenes or even whole episodes, such as Emily's stay at Udolpho, may be regarded as the dramatization of some sort of Gothic "Landscape with Banditti". The Apennine setting is indeed endowed with true Rosa-like appeal and Emily repeatedly feels she is surrounded by banditti (Udolpho, 302, 312, 402) of whom Montoni would be the captain $(304-305,358,397)$. She even sketches some of the men she sees from her window on the ramparts as "banditti, amid the mountain-view of her picture" (276). Reality turns into pictorial fantasy unless it was already a picture since "she had copied from nature".

Some scenes read as pictorial tableaux in which Gothic architecture sets off the wildness of the characters in order to create striking individual or group portraits. When Emily is tricked into following Barnardine across the court to see her aunt, a "portrait" of the bandit suddenly suspends the unfolding of the narrative, increasing the dramatic tension while adding a fantastic overtone to the whole episode. The representation of the ruffian seems to be based on one of Rosa's Figurine set into a scenographic architectural decor (354-346). First published around 1656, the Figurine are a series of engravings in the capriccio mode or the fantasy figure representing grotesque figures, individually or in small groups, caught in theatrical expressive poses and detached on a blank background (fig. 10 and 11). The collection enjoyed high popularity and was widely reproduced throughout the seventeenth and eighteenth centuries. The plates were familiar to both Loutherbourg and Mortimer, and inspired their own compositions (fig. 12). The first 
illustrated edition of The Mysteries of Udolpho (1799, London, J. and G. Robinson) actually represents the brigands of the fortress in the Pyrenees in the manner of Mortimer's Rosalike soldier-bandits, confirming the imaginary connections (fig. 13). ${ }^{13}$

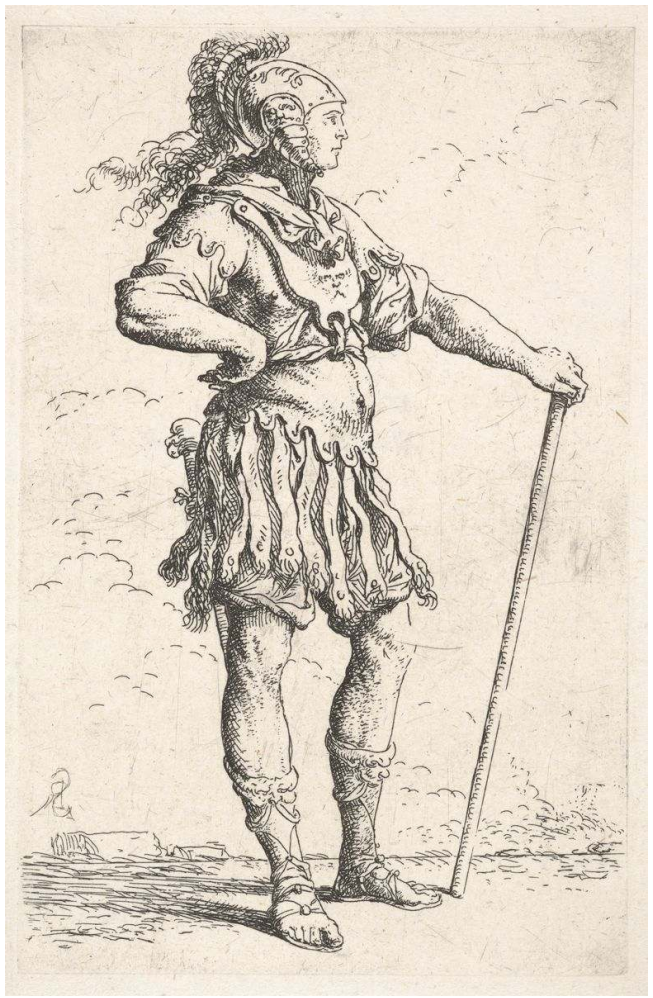

Fig. 10. Salvator Rosa, A Warrior Facing Right Wearing a Plumed Helmet and Holding a Staff, from the Series "Figurine" (c 1656-57), etching with drypoint, 14.3×9.2 cm, Metropolitan Museum of Art, New York. 


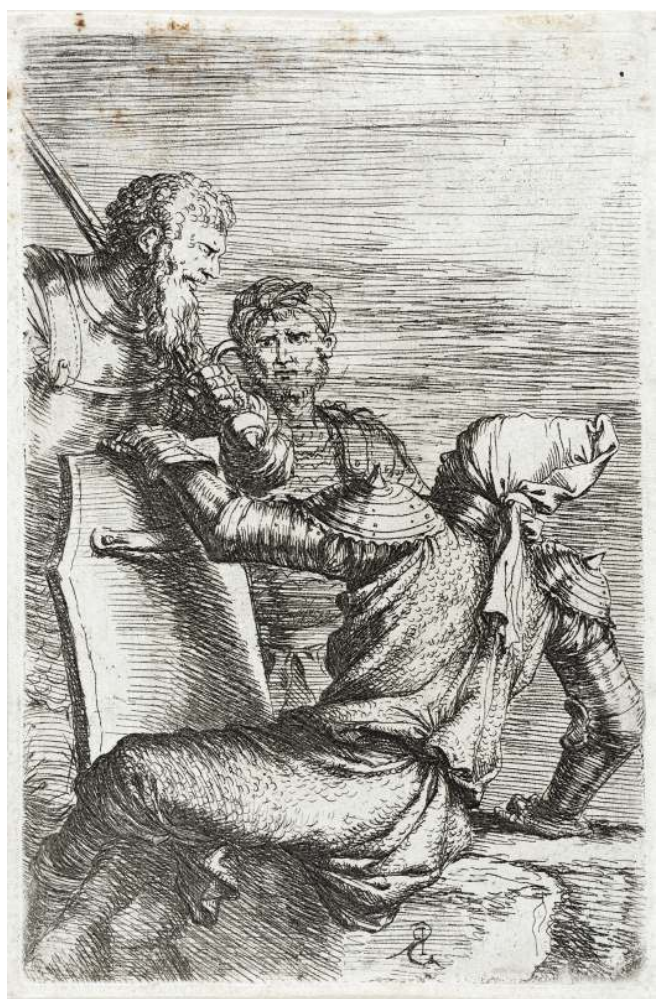

Fig. 11. Salvator Rosa, Figurine: Three Soldiers (c.1656-57), etching with drypoint, $14.61 \times 9.53 \mathrm{~cm}$, Los Angeles County Museum (LACMA).

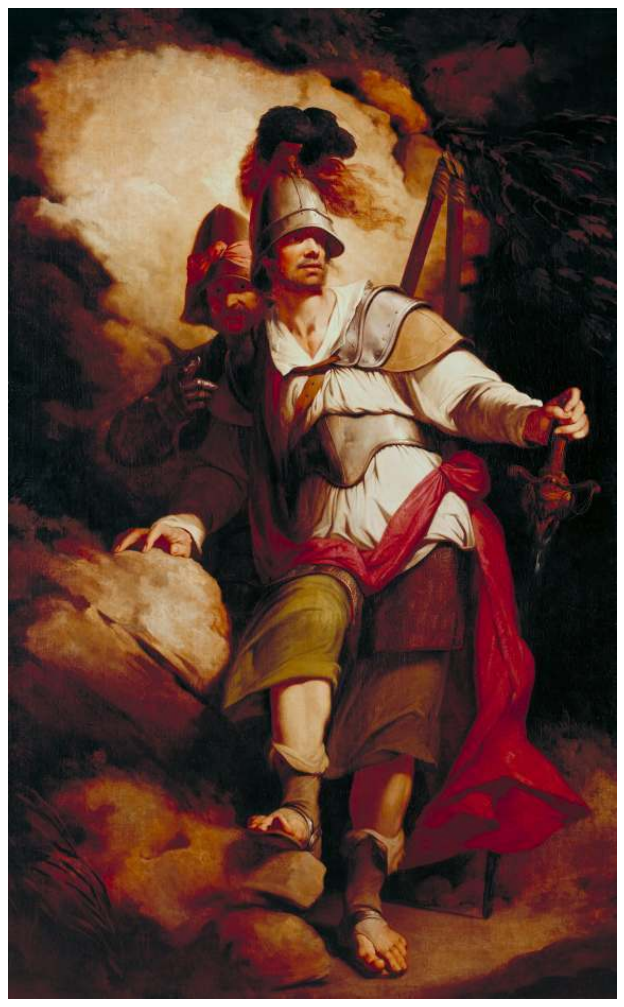

Fig. 12. John Hamilton Mortimer, Sir Arthegal the Knight of Justice, with Talus the Iron Man (From Spenser's Faerie Queen) (1778), oil on canvas, $242.6 \times 146$ cm, Tate Britain, London. (c) Creative Commons. 


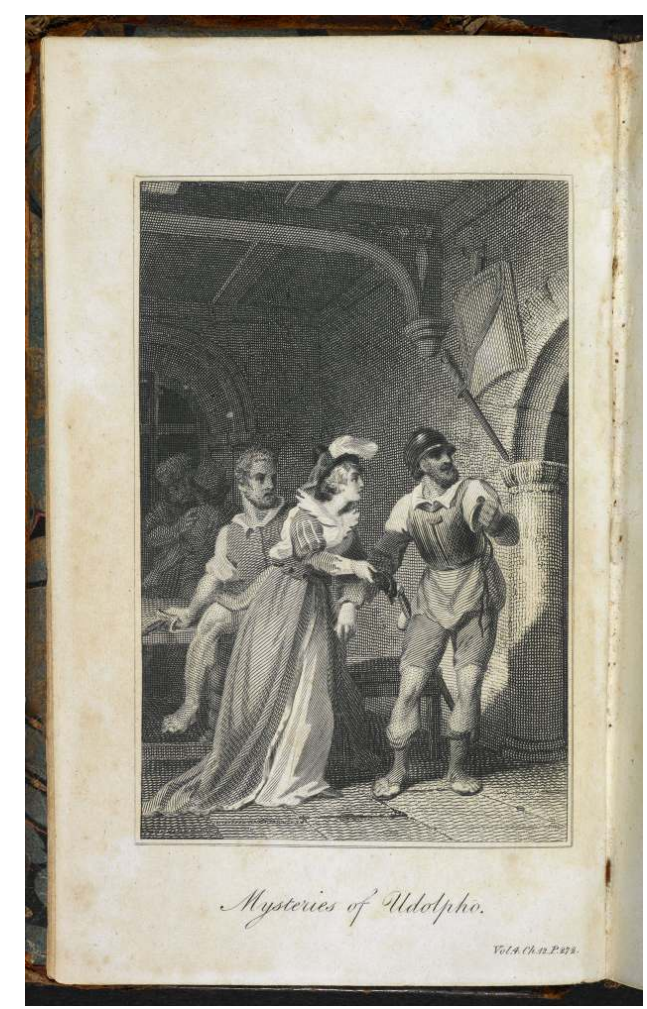

Fig. 13. Anonynous, The Mysteries of Udolpho, Illustrated with Copperplates (1803), frontispiece Vol. IV, copper engraving, $7.6 \times 12 \mathrm{~cm}$, London: J. and G. Robinson, 5th edition.

(c)British Library Board, 1508/384.

The Figurine are characterized by their extravagant appearance and mysterious air. Dressed in a mixture of contemporary fashion, ancient Roman clothes and weapons, and oriental outfits and accessories, their theatrical poses and emphatic gestures merge heroism with the grotesque. According to art historians, they possess a sort of "romantic incompleteness". Set against a neutral background and detached by the sharp line of the engraving, they seem to be waiting for some narrative investment (Langdon 188). The Figurine indeed provided a catalogue of figures for the amateurs of the picturesque to insert into their landscape drawings and create their own Rosa-like Landscapes with Banditti. The practice was recommended by Gilpin himself who praised Rosa's "Robbers" as suitable staffage (Gilpin 1768, 58; 1786, 174-175). Likewise, Radcliffe transposes the picturesque device into the world of romance to create striking picture-like scenes, placing banditti not just in natural landscapes but in Gothic architectural settings.

In her "Portrait of a Banditto", the novelist follows classical pictorial rules of composition in laying out the decor before inserting the figure:

As they crossed [the first court of the castle], the light shewed the high black walls around them, fringed with long grass and dank weeds, that found a scanty soil among the mouldering stones; the heavy buttresses, with, here and there, between them, a narrow grate, that admitted a freer circulation of air to the court, the massy iron gates, that led to the castle, whose clustering turrets appeared above, and, opposite, the huge towers and arch of the portal itself. (Udolpho, 345-346)

The dramatic lighting sets forward architectural and symbolic details that suggest claustrophobic closure, verticality and decay. Barnardine is then introduced wearing a grotesque outfit that recalls the extravaganza of Rosa's characters: 
In this scene the large, uncouth person of Barnardine, bearing the torch, formed a characteristic figure. This Barnardine was wrapt in a long dark cloak, which scarcely allowed the kind of half-boots, or sandals, that were laced upon his legs, to appear, and shewed only the point of a broad sword, which he usually wore, slung in a belt across his shoulders. On his head was a heavy flat velvet cap, somewhat resembling a turban, in which was a short feather; the visage beneath it shewed strong features, and a countenance furrowed with the lines of cunning and darkened by habitual discontent. (Udolpho, 346)

In a metatextual-or rather "metapictorial"-reflection, the vocabulary emphasizes the character's pictorial transformation from an individual "person" into a picturesque "figure". The description of the man has a strong visual dimension, with the use of a presentative THIS that brings him close to the reader-spectator-the deictic functioning like a pointing gesture on the part of the narrator-commentator-, coupled with the use of verbs such as "appear" and "show", the attention paid to details and the focus on the expression of the face, framed by the "turban-like cap". The typical ambiguity of the soldier-bandit is suggested by his undetermined shoes ("kind of half-boots or sandal), his unusual way of carrying the sword, while the "heavy flat velvet cap, somewhat resembling a turban" recalls the fancy exotic dress of the Figurine. As if to comfort the analogy, the pictorial metaphor merges writing and painting, denoting engraving as a technique: "a countenance furrowed with the lines of cunning and darkened by habitual discontent". The image completes the picture-like metamorphosis of the henchman by stressing the visual expression of passions as character and feelings can literally be read on the countenance. Such emphasis on physiognomy, which recalls Johann Kasper Lavater's theories, is a recurrent device that helps inscribe the pictorial within the textual through a visual representation of the passions. The sculptural metaphor also underlines the picturesque complementarity of the character and the stone decor.

The dinner scene with Montoni and his men offers another example of the use of an architectural decor to compose, this time, a group portrait of banditti. The pictorial reference is made explicit as Emily "again almost fancied herself surrounded by banditti". But this time the Gothic architecture, and not the usual mountainous landscape, provides the suggestion:

The scene, in which they sat, assisted the illusion; it was an antient hall, gloomy from the style of its architecture, from its great extent, and because almost the only light it received was from one large gothic window, and from a pair of folding doors, which, being open, admitted likewise a view of the west rampart, with the wild mountains of the Apennine beyond.

The middle compartment of this hall rose into a vaulted roof, enriched with fretwork, and supported, on three sides, by pillars of marble; beyond these, long colonades retired in gloomy grandeur, till their extent was lost in twilight. (Udolpho, 312)

The Piranesian architecture of the hall takes over the Salvatoresque mountainous landscape as a pictorial setting for a group portrait composed according to the theory of humours. The view on the Apennines, framed by open doors and projected in the background as a picture within the picture, offers a sort of metapictorial quote for the reading of the scene as a Gothic variation on the "Landscape with Banditti" clichés. The text focuses first on the figures of the banditti transposed from rocky landscapes into Gothic interiors. Their character is expressed in physionomical terms, two guests particularly standing out as doubles of Montoni. The first possesses his choleric temper associated with fire and an excess of yellow bile, the second embodies the phlegmatic type that characterizes Cavigni, his acolyte and gallant double (312). ${ }^{14}$ The repetition of 
the word "wild", first in reference to the banditti's countenance ("all had an expression [...] of wild fierceness") then the mountains, again shows a picturesque correlation between the figures and their surroundings. ${ }^{15}$ The decor functions as a stage-set that makes the picture complete. The Gothic architecture organises a truly pictorial space: the window provides the lighting source for a chiaroscuro while the pillars and columns mark successive planes, delineating strong vertical lines and giving a sense of infinite depth. The banditti indeed appear as "Figures in a Gothic architectural Landscape".

If the Gothic novel is the dramatization of an architecture (Lévy 1968, v), Radcliffe's romances may more precisely be considered as the dramatization of a syncretic "Landscape with Gothic Ruins and Banditti". Drawing on extradiegetical visual models and blending the sublime with the picturesque, her iconotextual reconstruction of Gothic architecture conjures up what has become an iconic decor in which Piranesian-like architectural capricci seem to fuse with Claudian twilight effects and Salvatoresque mountainous compositions. Her pictorial writing thus draws on the Zeitgeist but also departs from the Gothic Revival as it reflects her own personal aesthetics and her conception of writing as word-painting, which makes her both canonical and unique.

\section{BIBLIOGRAPHY}

Arasse, Daniel. Le Détail, Pour une histoire rapprochée de la peinture (1996). Paris : Flammarion, «Champs », 2005.

Barthes, Roland. «L'effet de réel » (1968). Littérature et réalité. Gérard Genette et Tzvetan Todorov (dir.). Paris : Éditions du Seuil, 1982, 81-90.

Besson, Françoise. « Les Pyrénées dans The Mysteries of Udolpho ou les mystères du paysage déplacé ». Les Mystères de Mrs Radcliffe, Nouveaux essais sur les Mystères d'Udolphe d'Ann Radcliffe (1794). Max Duperray (dir.). Aix-en-Provence : Publications de l'Université de Provence, 1999, 63-81.

Burke, Edmund. A Philosophical Enquiry into the Origin of our Ideas of the Sublime and the Beautiful (1757). Oxford: OUP, 1998.

Clery, Emma J. “Introduction". The Italian (1797), Oxford: Oxford UP, 2008, vii-xxi.

Charlesworth, Michael. "The Ruined Abbey: Picturesque and Gothic values". The Politics of the Picturesque: Literature, Landscape and Aesthetics since 1770. Stephen Copley, Peter Garside (eds.). Cambridge: CUP, 1994.

Durot-Boucé, Élizabeth. Le Lierre et la chauve-souris: Réveils gothiques. Émergence du roman noir anglais 1764-1824. Paris : Presses de la Sorbonne Nouvelle, 2004.

Ellis, Markman. The History of Gothic Fiction. Edinburgh: Edinburgh UP, 2000.

Flaxman, Rhoda. Victorian word-Painting and Narrative: Towards the Blending of Genres. Ann Arbor, Michigan: UMI Research Press, 1987. 
Gilpin, William. An Essay on Prints: Containing Remarks upon the Principles of Picturesque Beauty; the Different Kinds of Prints; and the Characters of the Most Noted Masters (1768). London: T. Cadell Jr. and W. Davies, 1802.

Gilpin, William. Observations on the River Wye, and Several Parts of South Wales etc., Relative chiefly to Picturesque Beauty: Made in the Summer of the Year 1770 (1782). London: T. Cadell Jr. and W. Davies, 1800.

Gilpin, William. observation on Several Parts of England, Particularly the Mountains and Lakes of Cumberland and Westmoreland, Relative Chiefly to Picturesque Beauty, Made in the Year 1772 (1786). London: T. Cadell Jr. and W. Davies, 1802.

Gilpin, William Remarks on Forest Scenery and Other Woodland Views, Relative chiefly to Picturesque Beauty (1791). London: J. Nisbet, 1887.

Gilpin, William. Three Essays: On Picturesque Beauty; On Picturesque Travel and On Sketching Landscape to Which Is Added a Poem On Landscape Painting (1794). Farnborough: Gregg International Publishers Limited, 1972.

Hamon, Philippe. Du descriptif. Paris : Hachette, 1993.

Labourg, Alice. “'Such a scene as Salvator would have chosen': Metapictorial Naming in The Mysteries of Udolpho and The Italian". Ann Radcliffe, the Enchantress of Words, Sounds and Images. Jakub Lipski and Jacek Mydla (ed.). Palo Alto: Academia Press, 2014, 21-51.

Labourg, Alice. « Entre peinture et écriture : figuration et défiguration du visage dans les romans gothiques d'Ann Radcliffe ». L'Écriture du visage dans les littératures francophones et anglophones, de l'âge classique au XXI siècle. Fabienne Gaspari (dir.). Paris : L'Harmattan, « Espaces Littéraires », 2016, 79-105.

Labourg, Alice. "'Fancy paints with hues unreal': Pictorial Fantasy and Literary Creation in Ann Radcliffe's Gothic Novels". Fancy-Fantaisie-Capriccio, Diversion and Subversion in Eighteenth-Century Visual Culture. Melissa Percival and Muriel Adrien (eds.). Oxford: Oxford University Studies in the Enlightenment, [forthcoming], 279-298.

Langdon, Helen (ed). Salvator Rosa. London: Paul Holberton Publishing, 2010.

Lévy, Maurice. Le Roman « gothique » anglais, 1764-1824 (1968). Paris : Albin Michel, « Bibliothèque de l'Évolution de l'Humanité », 1995.

Lévy, Maurice. Ann Radcliffe: The Mysteries of Udolpho. Paris : CNED, Didier-Érudition, 1996.

Louvel, Liliane. Poetics of the Iconotext. Farnham: Ashgate Publishing, 2011.

Lovejoy, Arthur et Michel Baridon. Le Gothique des Lumières. Brionne : Gérard Monfort Éditeur, 1991.

Martinet, Marie-Madeleine. «Le motif gothique : ruine et synecdoque ». Le Gothique et ses métamorphoses, mélanges en l'honneur de Maurice Lévy. Jean-Louis Breteau (dir.). Caliban 33 (février 1996) : 17-27.

Radcliffe, Ann. The Castles of Athlin and Dunbayne (1789). Oxford: OUP, 1995.

Radcliffe, Ann. A Sicilian Romance (1790). Oxford: OUP, 2008.

Radcliffe, Ann. The Romance of the Forest (1791). Oxford: OUP, 2008.

Radcliffe, Ann. The Mysteries of Udolpho (1794). Oxford: OUP, 2008.

Radcliffe, Ann. The Italian, or the Confessional of the Black Penitents (1797). Oxford: OUP, 2008. 
Radcliffe, Ann. "On the Supernatural in Poetry". The New Monthly Magazine and Literary Journal 16.1 (1826) [London: Henry Colburn]: 145-152.

Reeve, Matthew. "Gothic Architecture, Sexuality, and License at Horace Walpole's Strawberry Hill”, The Art Bulletin 95.3 (September 2013): 411-439.

Ronald, Ann. "Terror-Gothic: Nightmare and Dream in Ann Radcliffe and Charlotte Brontë". The Female Gothic. Juliann Fleenor (ed.). Montreal: Eden Press, 1983, 176-186.

Sedgwick, Eve Kosofsky. The Coherence of Gothic Conventions (1976). New York/London: Methuen, 1986.

Walpole, Horace. The Yale Edition of Walpole's Correspondance. S.W. Lewis (ed.). New Haven: Yale UP, 1983, Vol. 1 and Vol. 9.

\section{NOTES}

1. See Walpole's letter to Rev. William Cole, 9 March 1765 (Lewis, vol. 1, 88).

2. See Walpole's letter to George Montagu, 11 June 1753 (Lewis, vol. 9, 151).

3. Although Radcliffe makes a clear distinction between terror and horror in "On the Supernatural in Poetry", the two notions are sometimes confused in her early novels.

4. On the embroidery motif, see Besson.

5. On the notion of "word-painting", see Flaxman and Louvel.

6. For a definition of "iconotextual", see Louvel.

7. See Gilpin's definition of the picturesque as "that peculiar kind of beauty, which is agreeable in a painting" (1768, xii).

8. On Gilpin's influence on Radcliffe, see Lévy.

9. On the distinction between particolare and detaglio, see Arasse 11-12.

10. See Lovejoy, Baridon.

11. Part of the following development was first published in Alice Labourg, "'Fancy paints with hues unreal': Pictorial Fantasy and Literary Creation in Ann Radcliffe's Gothic Novels", FancyFantaisie-Capriccio, Diversion and Subversion in Eighteenth-Century Visual Culture. Melissa Percival and Muriel Adrien (eds.). Oxford: Oxford University Studies in the Enlightenment, [forthcoming], 279-298.

12. See Labourg 2014.

13. See Ellis 56-62. The 1803 edition used here as illustration reproduces the same plates.

14. See Labourg 2016.

15. Mountainous landscapes, Gothic architecture and banditti are all interrelated as manifestations of the sublime. The personification of the Gothic castle and its sublime "frown" echoes the "brow" of the mountains, which recalls the terrifying gaze of the Gothic villain, Mont oni, who has the mountain ontologically inscribed in his very name. 


\section{ABSTRACTS}

According to Maurice Lévy, a Gothic novel is "Gothic" because its writing is closely related to architecture, the story being the very dramatization of a building. The ruined Gothic castle, abbey or monastery is indeed a cliché of the genre, the prerequisite decor for any real action to happen. The aim of this paper is to explore the aesthetic dimension of Gothic architecture in Ann Radcliffe's novels, especially its pictorial and visual effects, from decorative emblematic details that stamp a building as "Gothic" to the creation of picturesque "tableaux" composed as true "paintings in words". This literary reconstruction of Gothic architecture echoes the reappropriation of Gothic forms by the Gothic Revival. Radcliffe transfers this ornamental Gothic into the realm of the novel, adapting the ancient style of the "Goths" to modern dramatic purposes. Characteristic Gothic motifs such as the painted window or the arch are used to create a sense of dread or reproduce compositional effects. Drawing on pictorial models and the picturesque qualities attributed to Gothic architecture, Radcliffe's descriptions generate "pictures", literary equivalents of the "Landscapes with [Gothic] Ruins" popular in her days. Finally, by inserting Rosa-like banditti into architectural settings, the novelist fuses the Gothic Revival in architecture with a subgenre then popular in painting, to compose her own Gothic "Landscapes with Banditti".

Selon Maurice Lévy, un roman gothique est "gothique " parce que son écriture est intimement liée à une architecture, l'histoire étant la dramatisation d'une demeure. Le château, l'abbaye ou le monastère médiéval en ruine sont en effet des clichés du genre, le décor indispensable à la survenue de toute action. Cet article se propose d'explorer la dimension esthétique de l'architecture gothique dans les romans d'Ann Radcliffe, en particulier ses effets picturaux et visuels, depuis ces détails emblématiques qui estampillent un bâtiment comme étant " gothique » à la création de tableaux pittoresques composés comme de véritables « peintures de mots ». Cette reconstruction littéraire de l'architecture gothique entre en résonance avec la réappropriation des formes médiévales par le renouveau gothique au XVIII ${ }^{\mathrm{e}}$ siècle. Radcliffe transpose ce gothique ornemental dans la sphère romanesque, réinterprétant le style ancien des "Goths » pour répondre aux finalités dramatiques modernes. Des motifs gothiques caractéristiques tels que les vitraux ou l'arche sont utilisés pour créer une atmosphère inquiétante ou produire des effets compositionnels. S'appuyant sur les modèles picturaux et les qualités pittoresques attribuées à l'architecture gothique, les descriptions de Radcliffe génèrent des "tableaux ", équivalents littéraires aux «Paysages avec ruines [gothiques] » alors en vogue. Enfin, en insérant des bandits à la manière de Salvator Rosa dans des décors architecturaux, la romancière fait converger le renouveau gothique en architecture et un sous-genre à la mode en peinture pour composer ses propres « Paysages avec Bandits » gothiques. 
INDEX

Mots-clés: architecture, gothique, paysage, tableau, ruines, pittoresque, bandits

Keywords: architecture, Gothic, landscape, painting, ruins, picturesque, banditti

oeuvrecitee Castles of Athlin and Dunbayne (The), Italian (The), Mysteries of Udolpho (The), Romance of the Forest (The), Sicilian Romance (A)

\section{AUTHORS}

\section{ALICE LABOURG}

Alice Labourg teaches English at Rennes-II University for undergraduate and graduate students in arts, literature and communication. She defended a PhD entitled "Painting and Writing: The Pictorial Imagination in Ann Radcliffe's Gothic Novels" (highest honour), which she is currently revising for publication. Her research focuses on text-image relations, in particular relations between writing and painting, questions of intertextuality, intermediality and intersemioticity, relations between literature and the visual arts, theoretical cross-readings between textual analysis and image analysis, aesthetics and visual semiotics, as well as on the British Gothic novel. 